\title{
Latihan Pengembangan Produk Kulit Kakao Kreakalut (Kreasi Kakao Salut) Di Desa Salut Lombok Utara
}

\author{
Sitti Latifah*1, Nirla Permatasari ${ }^{2}$, Shyntia Marisa ${ }^{2}$, Syarif Hidayatulloh ${ }^{2}$, Feni Mantika \\ Dewi $^{2}$, Hardiman², Muhammad Syafwan ${ }^{3}$, Deneq Bini DCWS ${ }^{3}$, Syamsiah ${ }^{4}$, Dina Faria Lestari \\ ${ }^{1}$. Fakultas Pertanian, Universitas Mataram*) \\ 2. Fakultas Ekonomi dan Bisnis, Universitas Mataram \\ 3. Fakultas Hukum, Universitas Mataram \\ ${ }^{4}$. Fakultas Peternakan, Universitas Mataram \\ 5 . Prodi Ilmu Komunikasi, Universitas Mataram \\ Jl. Majapahit No. 62, Mataram 83125, Lombok-Nusa Tenggara Barat
}

Kata Kunci:

Krekalut, Kripik Kulit kakao, Limbah Kakao, Desa Salut

\begin{abstract}
Abstrak: Kakao merupakan salah satu komoditas perkebunan utama yang dihasilkan oleh masyarakat P. Lombok, termasuk Desa Salut yang berlokasi di Kecamatan Kayangan, Kabupaten Lombok Utara. Selama ini masyarakat menjual komoditas kakao hanya dalam bentuk biji kakao yang dikeringkan, sementara kulit kakao ditinggalkan begitu saja dan menjadi limbah yang tidak termanfaatkan. Padahal kulit kakao memiliki kandungan kadar polifenol yang tinggi yang merupakan antioksidan. Antioksidan dalam kulit dan daging kakao ini lebih tinggi dari pada teh dan anggur merah. Berdasarkan pengetahuan kandungan kulit kakao, maka dicobakan untuk mengolah limbah kulit kakao dengan tujuan menjadikan kulit kakao memiliki nilai tambah sebagai bahan pangan yang bernilai ekonomis. Kegiatan pengabdian ini bertujuan untuk memberikan pelatihan ibu-ibu rumah tangga, pemuda dan anak-anak sekolah tingkat SMA mengenai proses pembuatan dan pengemasan produk kripik yang berbahan dasar kulit kakao (Krekalut), sehingga diharapkan dapat menjadi salah satu alternatif pengembangan kewirausahaan di Desa Salut. Metode pelaksanaan dilakukan dengan ceramah, diskusi dan praktek langsung pembuatan dan pengemasan produk KREKALUT ini yang secara keseluruhan dilaksanakan dalam waktu 1.5 (satu setengah) bulan melalui program KKN Tematik Universitas Mataram. Ketertarikan masyarakat untuk mengembangkan krupuk kulit kakao (Krekalut) ini, menunjukkan bahwa proses pengabdian yang telah dilaksanakan berhasil memotivasi masyarakat, khususnya kalangan pemuda dan anak-anak SMA untuk mengembangkan wirausaha produk-produk pangan, utamanya dari bahan-bahan dasar yang selama ini tidak termanfaatkan.
\end{abstract}

\section{Korespondensi: sittilatifah@unram.ac.id}

\section{PENDAHULUAN}

Berdasarkan statistik perkebunan Indonesia (2016), disampaikan bahwa komoditas perkebunan merupakan salah satu andalan pendapatan nasional. Hal tersebut diperlihatkan melalui nilai total ekspor komoditas perkebunan yang pada tahun 2015 mencapai US\$23,933 milyar atau setara dengan Rp 311,138 triliyun). Salah satu produk perkebunan yang mendunia adalah Kakao (Theobrema cacao). Kakao menjadi salah satu produk yang sangat penting bagi kehidupan masyarakat Indonesia, mengingat bahwa 95\% total produksi kakao 
Indonesia dihasilkan dari perkebunan rakyat. Nilai ekspor kakao pada tahun 2016 mencapai US\$ 895.165.000. Perkebunan kakao rakyat menyebar di seluruh Provinsi di Indonesia, termasuk Provinsi Nusa Tenggara Barat, dimana Kecamatan Kayangan dan khususnya Desa Salut berada.

Desa Salut merupakan salah satu Desa yang terletak di Kabupaten Lombok Utara, yang terkenal sebagai salah satu sentra penghasil kakao. Berdasarkan data statistik Dirjen Perkebunan tahun 2016, Kabupaten memiliki luas perkebunan kakao rakyat sebesar 3.6113 Ha, dengan produksi per hektarnya sebanyak $514 \mathrm{~kg}$ dan jumlah petani pengelola kebun kakao sebanyak 3.907 orang (40\% dari total jumlah petani kakao di Provinsi NTB). Mata pencaharian masyarakat Desa Salut mayoritas adalah beternak dan berkebun. Dengan lahan perkebunan seluar $674 \mathrm{Ha}$, Desa Salut menghasilkan berbagai komoditas perkebunan yang menggerakkan roda perekonomiannya, yaitu Kelapa, pinang, Kemiri dan Kakao (Profil Desa Salut, 2014). Perkebunan Kakao menyebar di seluruh Desa Salut, dengan mayoritas berada di 3 (tiga) dusun, yaitu : Salut Kendal, Salut Timur dan Salut Barat.

Kakao (Theobrema cacao) merupakan komoditas perkebunan yang hamper selalu memiliki nilai ekonomi yang tinggi dan stabil. Hal ini karena kebutuhan pasar masih sangat tinggi. Kakao merupakan komoditas yang berbuah tanpa musim, sehingga dapat dijadikan andalan pendapatan bagi masyarakat sepanjang tahun. Berdasarkan hasil wawancara dengan masyarakat Desa Salut oleh Nirla Permatasari (28 juli 2019), Kakao di Desa Salut dipanen sebanyak 1-2 kali sebulan tergantung tingkat kematangan kakao. Harga pasaran kakao untuk biji kering dijual harga Rp.32.000,-/kg dengan sekali panen diperoleh 110-130 kilogram/hektar. Sehingga diperkirakan bahwa pendapatan pendapatan Desa Salut dari produksi kopi setiap tahunnya dapat mencapai Rp. 748.800.0000,-

Hasil yang sudah cukup besar ini, sesungguhnya dapat ditingkatkan lagi nilainya, mengingat selama ini bagian kakao yang digunakan hanya bijinya saja. Sementara bagian lainnya, seperti kulit buah dan daun belum dimanfaatkan sama sekali. Hal ini diperkirakan karena ketidaktahuan atau kurangnya pengetahuan akan manfaat dari bagian lain dari kakao. Salah satu bagian buah kakao yang dapat dimanfaatkan dan berpotensi besar dalam meningkatkan nilai ekonomi kakao adalah bagian kulit buah kakao. Selama ini kulit buah kakao dibuang begitu saja dan menjadi limbah yang tidak berharga. Padahal kulit kakao memiliki kandungan kadar polifenol yang tinggi yang merupakan antioksidan. Antioksidan dalam kulit dan daging kakao ini lebih tinggi dari pada teh dan anggur merah. Ternyata, bagian antara lapisan pertama dan ketiga kulit buah kakao dapat juga dijadikan produk bernilai ekonomi, dengan memprosesnya menjadi makanan ringan berupa kripik. Proses pembuatan yang sangat sederhana dengan hanya mencampurkan beberapa bahan penunjang yang mudah didapat di sekitaran Desa Salut dan tahapan yang sangat mudah diadopsi oleh para ibu rumah tangga dan anak-anak muda, menjadikan kripik kulit kakao atau yang dinamakan KREKALUT menjadi salah satu produk yang kedepan memiliki potensi uang besar untuk dikembangkan.

Tujuan dari kegiatan pengabdian ini adalah :

1. Mensosialisasikan pemanfaatan limbah kulit kakao kepada masyarakat umum.

2. Melatih ibu-ibu rumah tangga, kelompok pemuda dan siswa SMA untuk membuat produk makanan ringan berupa kripik limbah kulit kakao (KREKALUT) 
3. Melatih pengemasan produk yang dihasilkan.

4. Memberikan pengetahuan pemasaran produk yang sederhana dengan menpergunakan media sosial.

Manfaat yang diharapkan dari kegiatan pengabdian ini adalah :

1. Tumbuhnya jiwa kewirausahaan, khususnya dikalangan ibu-ibu dan pemuda, untuk turut mengembangkan perekonomian Desa Salut pasca Gempa Lombok 2018.

2. Meningkatnya keterampilan dalam pembuatan, pengemasan sampai pemasaran produk pangan berbahan dasar limbah.

\section{METODE KEGIATAN}

Kegiatan pengabdian kepada masyarakat ini dilaksanakan selama 45 (empat puluh lima) hari dari Bulan Juli-Agustus 2019 melalui skema Kuliah Kerja Nyata (KKN) tematik Universitas Mataram di Desa Salut, Kecamatan Kayangan, Kabupaten Lombok Utara. Metode yang dipergunakan dalam kegiatan ini adalah partisipatif, yaitu metode pendekatan yang melibatkan langsung secara aktif para peserta pelatihan, yaitu ibu-ibu rumah tangga, para pemuda dan siswa SMA di Desa Salut. Kegiatan diisi dengan diskusi-diskusi bersama warga, aparat pemerintah desa di Desa Salut dan praktek pembuatan, pengemasan dan proses pemasaran.

\section{HASIL DAN PEMBAHASAN}

Pengembangan produk KREKALUT di Desa salut ternyata mendapatkan respon yang positif dari masyarakat, terbukti dari antusias pengenalan produk KREKALUT yang harus dilaksanakan beberapa kali. Berikut adalah proses pengembangan produk KREKALUT :

\section{Tahap Persiapan}

Tahap persiapan diawali dengan koordinasi anggota fasilitator dengan desa yang kemudian ditindaklanjuti oleh kegiatan sosialisasi pada awal Juli 2019. Kegiatan sosialisasi dimulai dengan menyebarkan surat kepada para kader dan seluruh kepala dusun Desa Salut untuk diteruskan kepada masyarakat. Kegiatan sosialiasi pengenalan produk ini dihadiri oleh para warga dan perangkat desa. Proses sosialisasi ini menargetkan masyarakat terutama ibuibu PKK dan pemuda dengan tujuan untuk mengembangkan produk KREAKALUT sebagai upaya peningkatan nilai produk.

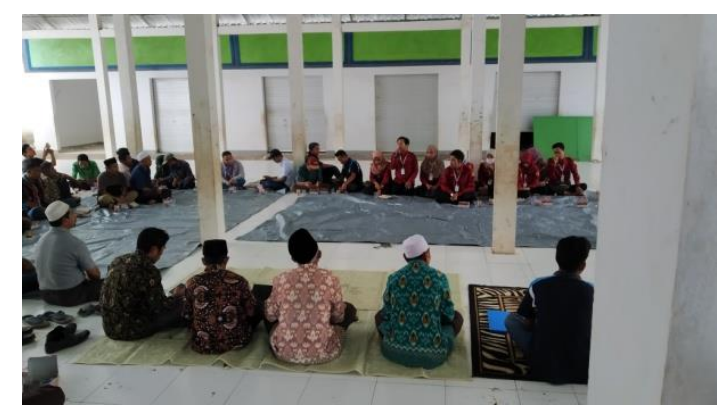

Gambar 1. Sosialisasi di Kantor Desa 


\section{Tahap Pelaksanaan}

Pada tahap pelatihan ini, kegiatan diawali dengan penyiapan materi dan alat oleh para fasilitator. Adapun alat-alat yang digunakan adalah : pisau, blender, baskom, dandang, kompor, penggilingan, wajan, dan sepatula. Sementara bahan yang digunakan dalam proses pembuatan keripik kulit kakao (KREKALUT) berupa buah kakao, tepung terigu, bawang merah, bawang putih, ketumbar, terasi, garam, dan penyedap rasa.

Pelatihan dilakukan di 2 dusun diantaranya Dusun Salut Kendal dan Dusun Salut Timur dengan tahapan pelatihan sebagai berikut:

\section{a) Pelatihan Pembuatan Produk}

Berikut adalah tahapan Pelatihan pembuatan produk :

\section{- Pengumpulan buah kakao}

Langkah awal yang dapat kita lakukan adalah mengumpulkan buah kakao yang diperlukan sebagai bahan utama pembuatan keripik kulit kakao

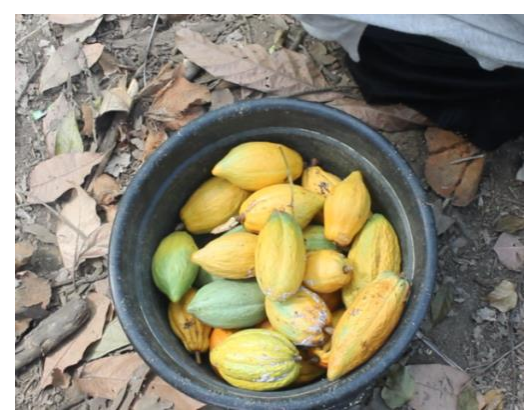

Gambar 2. Pengambilan Kakao

\section{- Pengupasan kakao}

Kakao yang telah dikumpulkan dan dipilih, kemudian dibelah dan dibuang bijinya.

Setelahnya dikupas tipis kulit lapisan pertamanya.

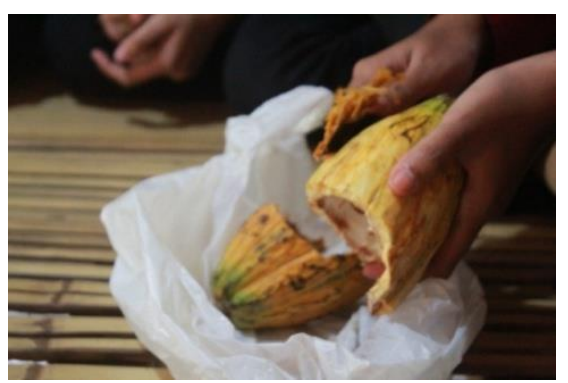

Gambar 3. Pengupasan Kakao 


\section{- Pencucian}

Setelah dikupas kulit kakao kemudian dicuci bersih di air mengalir.

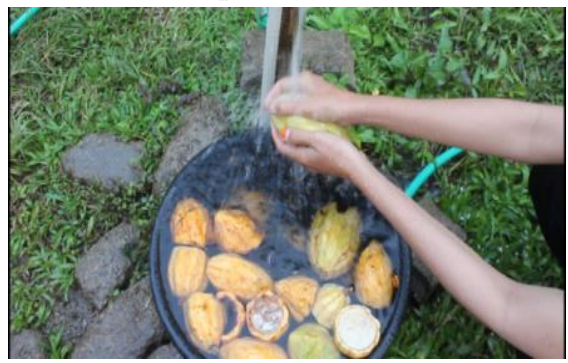

Gambar 4. Pencucian Kakao

\section{- Pengukusan tahap I}

Kakao yang sudah dicuci bersih, kemudian dikukus selama 20 menit atau hingga lunak.

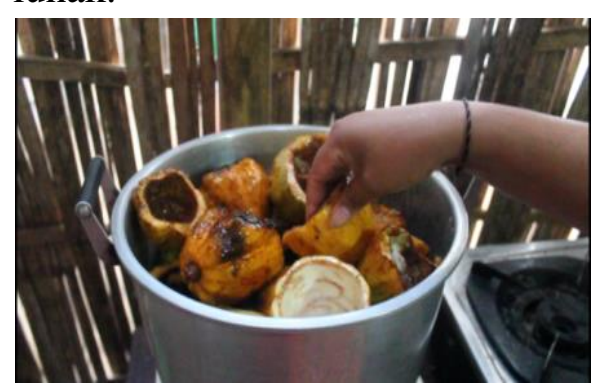

Gambar 5. Pengukusan Tahap I

\section{- Pengirisan}

Kakao yang sudah dikukus kemudian diiris tipis pada kulit lapisan keduanya sampai terasa kulit kerasnya.

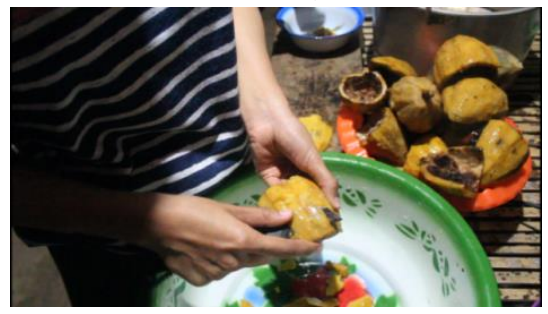

Gambar 6. Pengirisan

\section{- Penghalusan bumbu}

Semua bumbu dihaluskan menggunakan blender.

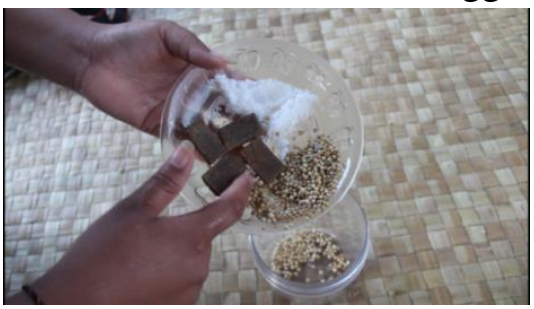

Gambar 7. penghalusan bumbu 


\section{- Pencampuran I}

Bumbu yang telah dihaluskan lalu dicampur dengan kulit kakao yang sudah diiris, kemudian diblender hingga halus.

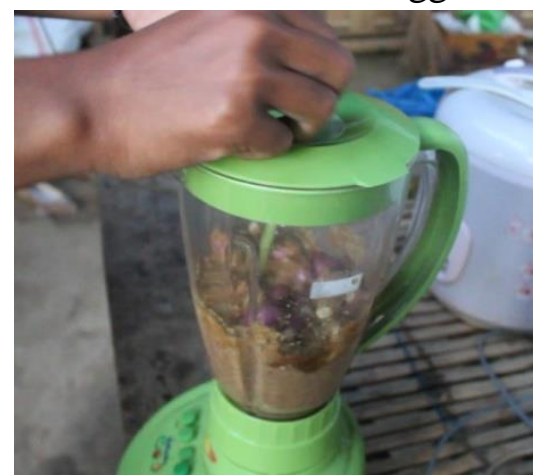

Gambar 8. Pencampuran I

\section{- Pencampuran II}

Adonan yang telah dihaluskan kemudian dicampur dengan tepung terigu hingga kalis.

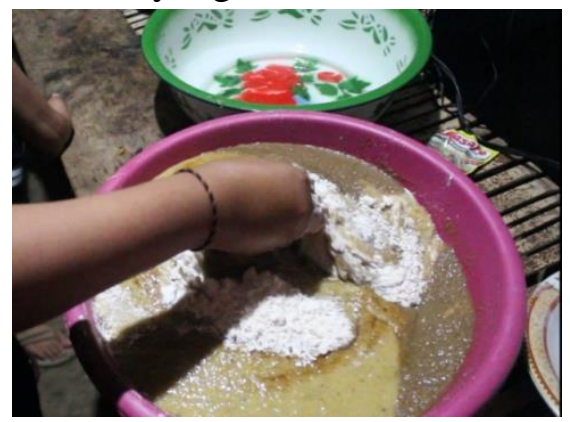

Gambar 9. pencampuran tahap II

\section{- Pemipihan}

Adonan yang sudah kalis kemudian dipipihkan diatas daun pisang hingga tipis.

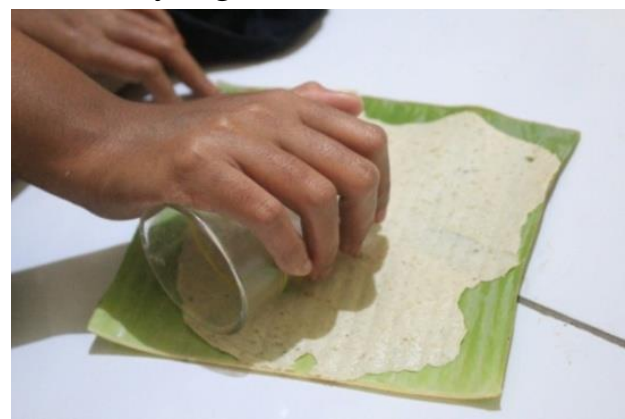

Gambar 10. Pemipihan

\section{- Pengukusan tahap II}


Setelah adonan dipipihkan kemudian dikukus selama 30 menit sampai adonan tidak menepel pada daun pisang.

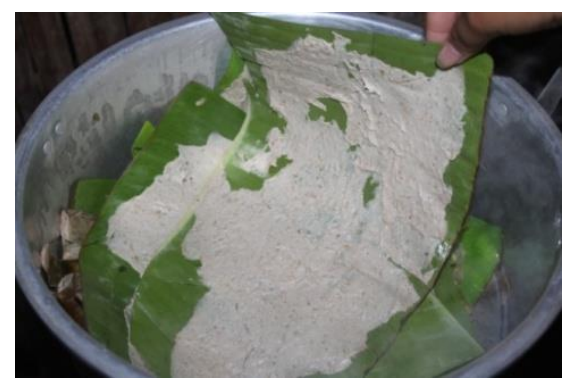

Gambar 11. Pengukusan Tahap II

\section{- Pengguntingan}

Adonan yang telah dikukus diangkat, kemudian digunting sesuai selera.

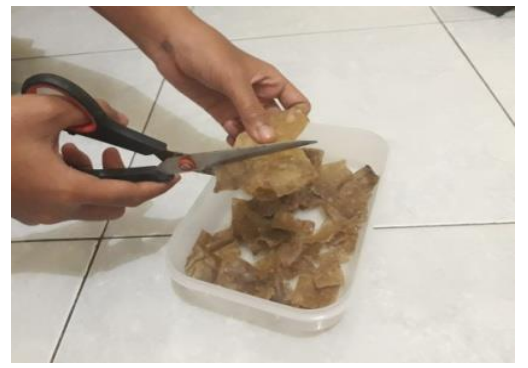

Gambar 12. Pengguntingan

\section{- Pengeringan}

Adonan yang telah digunting kemudian dikeringkan dengan cara dijemur.

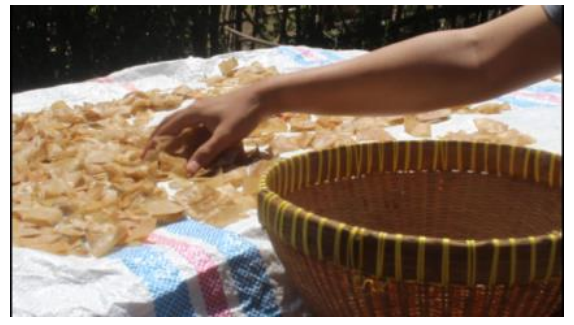

Gambar 13. Pengeringan

\section{- Penggorengan}

Setelah kering, keripik di goreng

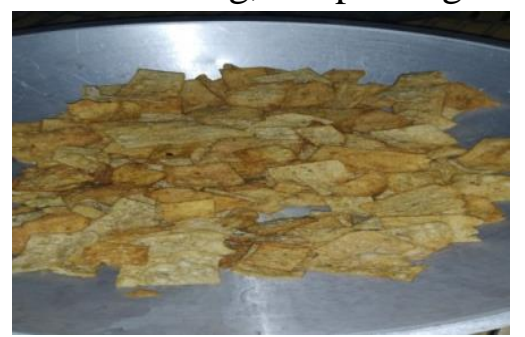

Gambar 14. Penggorengan 
Setelah melakukan pembuatan tersebut dapat diketahui sifat-sifat dari hasil olahan keripik kulit kakao tersebut antara lain:

- Keripik yang dihasilkan berwarna kuning keemasan apabila tidak dicampur pewarna dan perisa makanan.,

- Teksturnya renyah dan krispi,

- Rasanya sesui dengan perisa makanan yang ditambahkan

Hal yang harus diperhatikan dalam pembuatan produk adalah ketelitian dan perpaduan kadar zat yang harus sesuai agar menghasilkan produk yang baik. Hal-hal yang diamati adalah peran tepung terigu, ketumbar, bawang putih, bawang merah, terasi, garam, masako, dan perisa makanan. Selain itu terdapat dua factor yang mempengaruhi produk kripik ini yaitu :

a. Cahaya Matahari

Panas dari cahaya matahari sangat besar pengaruhnya terhadap pembuatan keripik kulit kakao. Keripik kulit kakao yang tidak kering saat proses penjemuran akan menyebabkan keripik yang dihasilkan tidak krispi dan alot.

b. Panas Minyak Goreng

Minyak goreng yang terlalu panas akan menyebabkan keripik gosong tetapi bagian dalamnya belum matang. Diajurkan minyak tidak terlalu panas agar mendapatkan hasil yang sesuai dengan keinginan.

Setelah proses pembuatan, maka pelatihan dilanjutkan dengan proses pengemasan dan penjualannya, sebagai berikut:

\section{b) Pengemasan}

Dalam tahap pengemasan ini perlu dilakukan penambahan perisa makanan seperti rasa jagung manis dan balado yang bertujuan untuk menambah cita rasa pada keripik kulit kakao.

Berikutnya keripik yang telah ditambahkan perisa makanan dikemas menggunakan aluminium-foil dan diberi label agar terlihat rapi dan menarik.

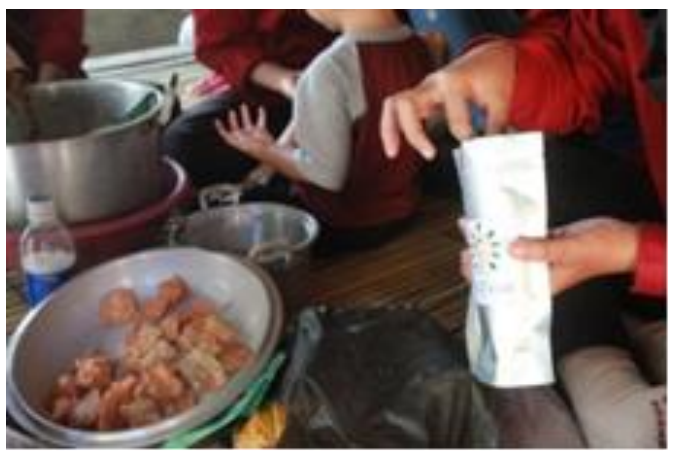

Gambar 15. Pengemasan

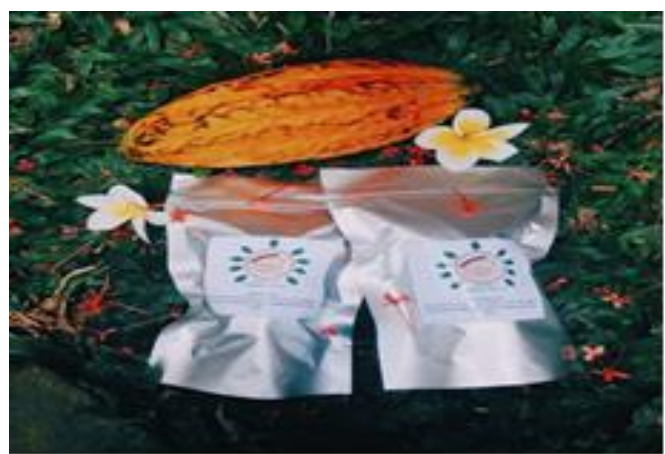

Gambar 16. Produk siap dijual 


\section{c) Pemasaran}

Untuk memasarkan produk kripik kulit kakao ini dilakukan melalui jejaring social seperti instagram, twitter dan facebook mengingat jaman sekarang orang lebih banyak berbelanja melalui online daripada turun langsung kepasar.

\section{Tahap Evaluasi}

Tahap evaluasi dilaksanakan pada masa akhir pengabdian, dimana pengukuran dilakukan berdasarkan antusiasme ibu-ibu rumah tangga, pemuda dan siswa SMA uang menjadi peserta pelatihan serta dari produk yang telah dihasilkan, yaitu kripik kulit kakao "KREKALUT" dalam kemasan cantic dan siap dijual.

\section{KESIMPULAN DAN SARAN}

\section{Kesimpulan}

Pemanfaatan kulit kakao menjadi produk olahan seperti keripik kulit kakao ini san gat memiliki potensi untuk dikembangkan sebagai usaha agroindustri baru bagi produsen. Karena selain rasanya yang enak, keripik kulit kakao ini juga memiliki antioksidan yang tinggi dan baik untuk kesehatan kulit dan tubuh. Dari hasil kegiatan pengabdian pelatihan kulit kakao (coklat) menjadi keripik kulit kakao, dapat disimpulkan bahwa untuk mengembangkan kripik kulit kakao sebagai produk bahan pangan alternatif menjadi usaha industri rumah tangga maka diperlukan tahapan mulai dari proses sosialisai, pelatihan pembuatan, pengemasan sampai dengan penjualan. Akan tetapi didapatkan pengalaman bahwa dalam pembuatannya diperlukan ketelitian dalam penggunaan zat. Selain itu preferensi konsumen juga menjadi pertimbangan dalam pengembangan rasa dari kripik kakao. Melalui kegiatan ini ternyata asyarakat menjadi sangat termotivasi dengan adanya pelatihan pengolahan keripik kulit kakao, sehingga menurut mereka pelatihan tersebut memberikan kreasi baru dalam pengolahan buah kakao dan menjadi bahan olahan baru yang dapat meningkatkan penghasilan masyarakat Desa Salut.

\section{Saran}

Saran yang dapat penulis kemukakan dalam rangka upaya mengembangkan kripik kulit kakao ini adalah:

a. Perlu diadakan penelitian lebih lanjut untuk dapat lebih meningkatkan kualitas produk yang baik.

b. Perlu diperhatikan penggunaan bahan dan zat dalam proses pembuatan agar mampu menghasilkan produk yang baik dan tetap (cita rasa selalu terjaga).

c. Pemerintah dan instansi (universitas mataram) diharapkan dapat mengembangkan kulit kakao sebagai bahan pembuatan produk olahan.

\section{Ucapan Terima Kasih}

Ucapan terima kasih disampaikan kepada Kepala Desa Salut Bapak Mustawa S.Adm dan Masyarakat Desa Salut yang telah menunjukkan antusiasnya dalam pelatihan ini. 


\section{DAFTAR PUSTAKA}

Direktorat Jenderal Perkebunan. 2016. Statistik Perkebunan Indonesia-Cacao 2015-2017. Kementrian Pertanian RI. Jakarta

Https://youtu.be/oz-ZviSSkgo. Diunduh pada 18 juni 2019, 17.12 wita

Https://youtu.be/p6CyPpEE@o4.Diunduh pada 18 juni 2019, 17.12 wita

Https://doktersehat.com/kandungan-cokelat/, Diunduh pada 2 September 2019, 14.39 wita

Https://id.m.wikipedia.org/wiki/kakao. Diunduh pada tanggal 2 september 2019, 17.12 wita

Https://laskarpemberani-wordpress-com.cdn.ampproject.org. Diunduh pada 2 September 2019, 14.39 wita

https://medium.com/@indotesis/jenis-kandungan-manfaat-dan-pengolahan-cokelat68656cd09758, 2 September 2019, 14.39 wita

Jkp.unram.ac.id/index.php/JK. Diunduh pada 9 september 2019, 17.01 wita

LPPM Unram. Tim Layanan KKN Tematik, Lembaga Pengabdian Masyarakat. Survey, Perancangan, Tema, Program \& Penulisan Proposal KKN Tematik, 2018. Mataram. Universitas Mataram. Diunduh pada 9 september 2019, 17.01 wita

Tim LPPM UNRAM. 2018. Buku Panduan KKN Pemberdayaan Masyarakat UNRAM. Mataram. Universitas Mataram. Diunduh pada 9 september 2019, 17.01 wita 